\title{
Ant diversity inhabited oil palm plantations in a peatland in Sumatra, Indonesia
}

\author{
ASNI JOHARI ${ }^{1, \bullet}$, M. ASEP HERMANTO ${ }^{2, \bullet \bullet}$, TIA WULANDARI ${ }^{2, \bullet \bullet \bullet}$ \\ ${ }^{1}$ Department of Mathematical and Natural Science Education, Faculty of Mathematics and Natural Sciences, Universitas Jambi. Jl. Raya Jambi-Muara \\ Bulian Km 15, Mendalo Darat, Muaro Jambi 36361, Jambi, Indonesia. Tel./fax. +62-271-663375, `email: johari_asni@yahoo.com \\ ${ }^{2}$ Faculty of Science and Technology, Universitas Jambi. Jl. Raya Jambi-Muara Bulian Km 15, Mendalo Darat, Muaro Jambi 36361, Jambi, Indonesia. \\ •vemail: hermantoasep63@gmail.com, vvvtiawulandari88@gmail.com
}

Manuscript received: 29 June 2021. Revision accepted: 25 August 2021

\begin{abstract}
Johari A, Hermanto MA, Wulandari T. 2021. Ant diversity inhabited oil palm plantations in a peatland in Sumatra, Indonesia. Nusantara Bioscience 13: 158-163. Ant community is one of the soil biotic components with diverse roles, including pollinators, predators, decomposers, parasites, and herbivores. Changes in land use from natural habitats to plantations affect the diversity and composition of ants because these groups are very vulnerable to environmental changes. The purpose of the study was to analyze the diversity of ants (Formicidae) found in peatlands planted with oil palms. The study was conducted on peatland in Gambut Jaya village, Sungai Gelam sub-district, Muaro Jambi district, Indonesia, from October 2019 to May 2020. The research was conducted through surveys in two peatland locations (natural peatland and oil palm plantation) using the purposive sampling technique through transect making, field sampling, sample preparation, and identification. A total of 2,636 ants were collected from natural peatlands, while 3,183 individuals were found in oil palm plantations. Eight ant species were identified from both study sites belonging to four subfamilies: Dolichoderinae, Formicinae, Myrmicinae, and Ponerinae. Among the species, Dolichoderus thoracicus were most dominant, composed of $63.6 \%$ in natural peatland and $73.6 \%$ in oil palm plantation. The diversity index of ant species in natural peatland was higher (0.97) than that in oil palm plantations (0.88), indicating the change in the abundance and diversity of ant species in oil palm plantations. Therefore, efforts to preserve the habitat of ants by maintaining their microhabitat and resource, as well as conserving the important species such as natural enemies of pests, need to be taken into account in peatland management.
\end{abstract}

Keywords: Ant type, diversity, palm plants, peatlands

\section{INTRODUCTION}

Palm oil is one of Indonesia's leading commodities, mostly developed on peatlands. To meet national and global demand, extensive forest landscape conversion to oil palm plantations occurred rapidly between the mid-1990s and 2015 (Tsujino et al. 2016). However, the conversion of peatlands into palm oil plantations involves many physical activities, such as land clearing and drainage channels that change peatlands' physical and chemical properties (Wang and Foster 2015). These changes have affected directly or indirectly the local organisms and thus led to a diversity crisis (Sodhi et al. 2010). For example, one of the local organisms that inhabited peatland areas is the ant (Hymenoptera).

In addition to oil palm plantations, studies of ant diversity have been carried out in many plantation habitats, including coffee (Urrutia-Escobar and Armbrecht 2013), mango (Carvalheiro et al. 2012; Diame et al. 2015), citrus (Calabuig et al. 2015; Martínez- Ferrer and Campos-Rivela 2017), rubber (Hosoishi et al. 2013), and eucalyptus (Suguituru et al. 2011; de Queiroz et al. 2020). That is due to the simplification of the agroecosystems because industrialization of agriculture can lead to the loss of animal biodiversity related to both vertebrates and invertebrates (Urrutia-Escobar and Armbrecht 2013; de Queiroz et al. 2020), which is due to changes in resources for the survival of ants. Another attraction for ants is their very complex functional role in the ecosystem. Ants have several main roles in an ecosystem, including pollinators, predators, decomposers, parasites, and herbivores (Kovar et al. 2013). Furthermore, the ants have the potential to transform soil litter into organic matter and as an environmental balancer. They have a narrow tolerance for environmental changes and can be used as bioindicator organisms (Fitzherbert et al. 2008; Chen et al. 2011). The ability of ants as bioindicators is generally studied at the community level. A study of ant communities' ability to restore the forest in Brazil showed that species composition changes with the recovery gradient and the dissimilarity between ant species composition in grassland and forest habitat increases with the age of the remaining forest. In addition to changes in composition, the presence of indicator species also supports ants' ability as bioindicators. Variations in ant species composition from both groups of habitat types (grassland and forest) were caused by differences in the responses of open habitat ants and forest specialist ants to the increase in vegetation cover along the recovery gradient (Schmidt et al. 2013). Therefore, ants in peatlands are ideal insects to determine the state of the peatland ecosystem.

Several studies of ant communities in peatlands planted with oil palm and adjacent natural habitats have been reported (Lucey et al. 2014; Darmi et al. 2015; Wang and 
Foster 2015; Rizali et al. 2020). Previous research by Darmi et al. (2015) compared the differences in ant communities in the oil palm stands with different ages. However, this study lacks a non-oil palm habitat comparison. A study comparing ant communities between natural forests and oil palm plantations was conducted by Yulminarti et al. (2012) focused on ant population ratios. Bruhl and Eltz (2010) studied the loss of forest ant species in oil palm plantations in Sabah, Malaysia. The study of Hardianti et al. (2019) evaluated ant communities on peatlands in Kalimantan. These studies generally only use the pitfall trap method. Research using a combination of pitfall trap and monolith methods is rarely done. Therefore, it is important to study ant communities (Hymenoptera: Formicidae) on peatlands planted with oil palm with more varied methods to evaluate the ants that inhabited the studied habitat.

Sungai Gelam is located in Jambi Province, Sumatra, Indonesia. The area has approximately 2,568 ha of peatland ecosystems. However, some peatlands in the area have been converted, including oil palm plantations. Changing the function of peatlands causes conditions on the surface of peatlands to change a lot. Differences in environmental conditions on peatland without oil palm and peatland with oil palm plantations are thought to affect the presence of ant species. This study aims to determine the diversity of ant species found on peatland without oil palm and peatland with oil palm plantations. The study results are expected to be used as input in peatland management.

\section{MATERIALS AND METHODS}

The study was conducted on peatland in Gambut Jaya Village, Sungai Gelam Sub-district, Muaro Jambi District, Jambi Province, Indonesia (Figure 1), from October 2019 to May 2020. The stages of this research consisted of sampling in the field, sample preparation, measurement of physical and chemical factors, data analysis, and identification.

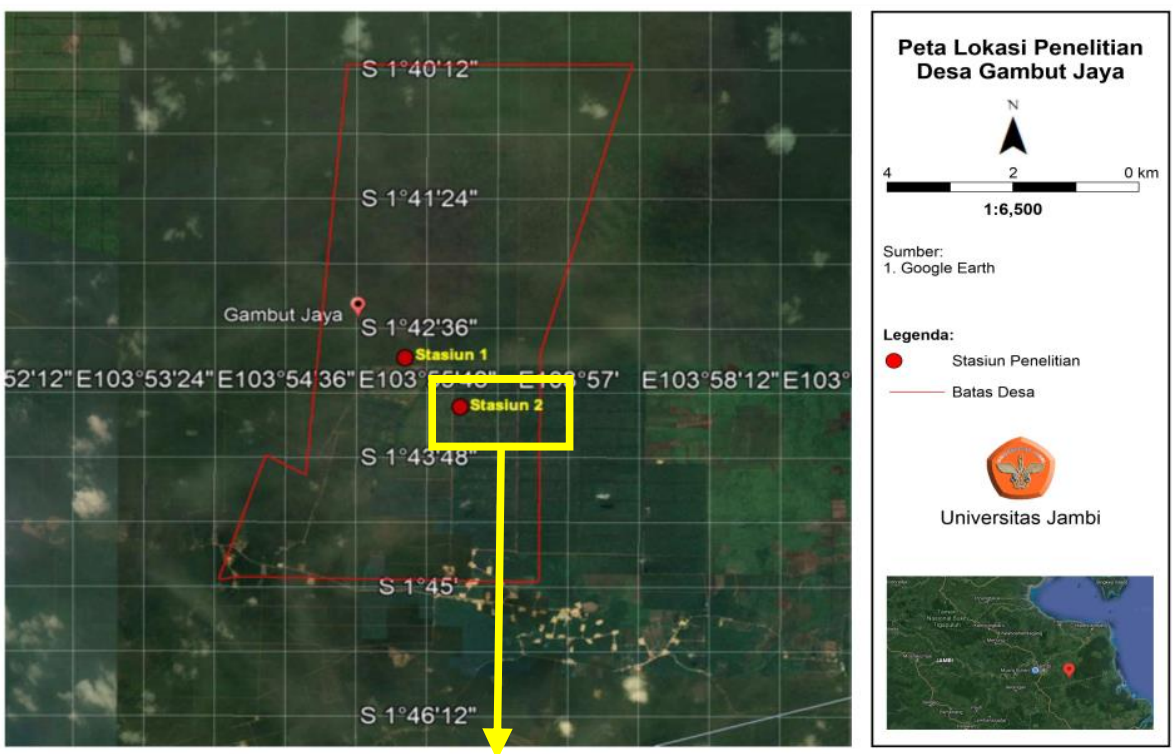

Pitfall traps and monoliths placement in a station

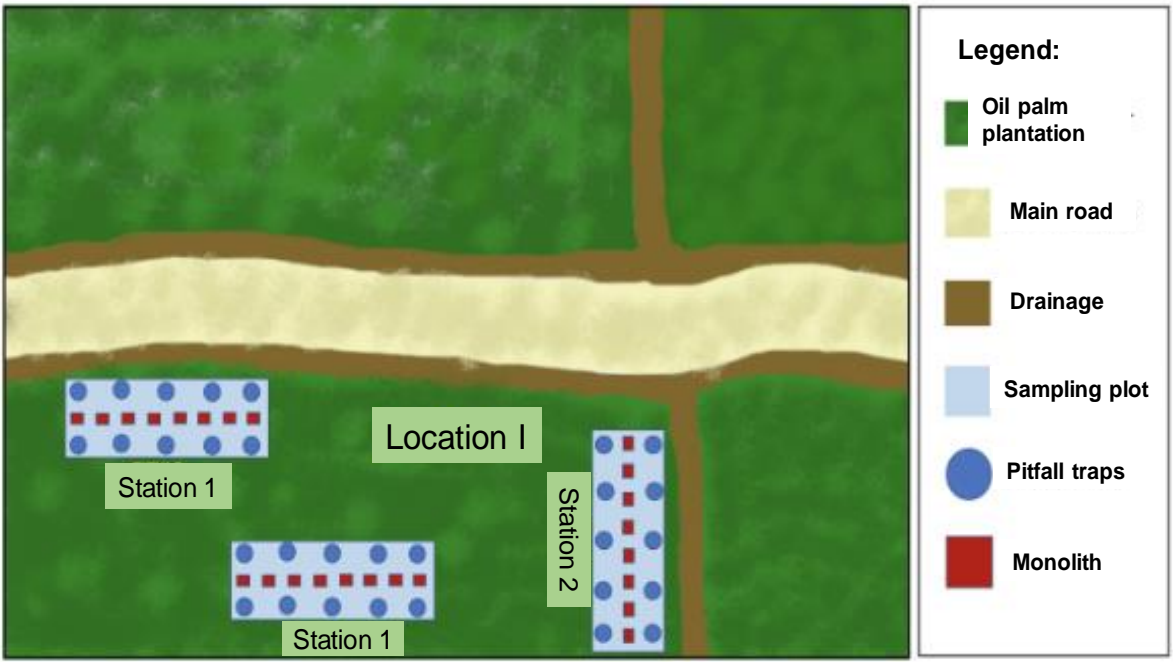

Figure 1. Map of research locations and trap placement design in Gambut Jaya Village, Muaro Jambi District, Indonesia 
The pitfall trap and the monolith methods were applied to collect the samples. A total of 60 pitfall traps were installed in the ground, consisting of 30 at each station, with a distance between plots was 10 meters. The pitfall trap method, consisting of a plastic cylinder measuring $10 \mathrm{~cm}$ in diameter and $15 \mathrm{~cm}$ in height, was buried in the soil until its open tip was leveled at the soil surface. The traps were filled with alcohol and a few drop of detergent. The traps were maintained for 24 hours in the field. Meanwhile, 48 units of monoliths were used, consisting of 24 units at each station. The monolith was placed at a distance between plots was 5 meters. Soil Monolith $(25 \times 25 \mathrm{~cm})$ was used to sample $5 \mathrm{~cm}$ wide and $10 \mathrm{~cm}$ depth of soil and litter outside the monolith (Figure 1). The sampling frequency was repeated 3 times. Ant species are identified based on morphological characteristics, referring to the book by Yoshimoto (2003). The identified samples were analyzed for species diversity index, evenness, and similarity index.

Furthermore, the value of the analysis results is classified based on Odum and Barrett (2004). The diversity index is classified as follows: low ( $\mathrm{H}^{\prime}$ less than 1$)$, medium ( $\mathrm{H}^{\prime}$ ranges from 1 to 3 ), and high ( $\mathrm{H}^{\prime}$ more than 3 ). The Species Evenness index is classified as follows: low (E less than 0.4 ), moderate ( $\mathrm{H}^{\prime}$ ranges from 0.4 to 0.6 ), and high ( $\mathrm{H}^{\prime}$ more than 0.6$)$. Finally, the similarity index is classified as low (SI less than 50\%) and high (SI more than 50\%).

\section{RESULTS AND DISCUSSION}

\section{Results}

A total of 2,636 ants were collected from natural peatlands, while 3,183 individuals were found in oil palm plantations. Eight ant species were identified from both study sites belonging to four subfamilies: Dolichoderinae, Formicinae, Myrmicinae, and Ponerinae. The Dolichoderinae subfamily has dominated the samples from both study sites. Among the species, Dolichoderus thoracicus were most dominant, composed of $63.6 \%$ in natural peatland and $73.6 \%$ in oil palm plantation. In addition, the ant species Oecophylla smaradigna was only collected from an oil palm plantation with two specimens (Table 1). Therefore, there were differences in the number of individuals and the number of species found in the two study sites.

The results of the data analysis of the Diversity Index, Similarity, and Dominance of ants at the two research locations are presented in Figure 3. The diversity index at both locations is categorized as low $(<1)$, the dominance index is moderate, and the similarity index is high $(>0.8)$. Ant diversity in Natural peatland was higher than in oil palm plantations (Figure 2).

In addition to the results presented above, physical environmental and chemical factors measurements were also carried out at the two research sites. Physical environmental factors are used to see the relationship with the presence of ants. Physical environmental factors largely determine ant activity. For example, the light intensity, aerial temperature, and soil temperature in Natural peatlands were higher than those in oil palm plantations, while soil humidity was lower (Table 2).

Table 1. Types and Number of Ants found on peatland with and without oil palm.

\begin{tabular}{llcc}
\hline \multirow{2}{*}{ Subfamily } & \multicolumn{1}{c}{ Species } & \multicolumn{2}{c}{ Abundance } \\
\cline { 2 - 4 } Folutichoderinae & $\begin{array}{l}\text { Dolichoderus } \\
\text { peatland } \\
\text { Formicinae }\end{array}$ & 1677 & $\begin{array}{c}\text { Oil palm } \\
\text { plantation }\end{array}$ \\
\hline & $\begin{array}{l}\text { Anoplolepis } \\
\text { gracilipes }\end{array}$ & 641 & 127 \\
& $\begin{array}{l}\text { Euprenolepis } \\
\text { procera }\end{array}$ & 254 & 463 \\
& $\begin{array}{l}\text { Camponatus } \\
\text { arrogans }\end{array}$ & 4 & 49 \\
& $\begin{array}{l}\text { Camponotus } \\
\text { penssylvanicus }\end{array}$ & 31 & 137 \\
& $\begin{array}{l}\text { Oecophylla } \\
\text { smaradigna }\end{array}$ & 0 & 2 \\
Myrmicinae & $\begin{array}{l}\text { Pheidole } \\
\text { megachepala }\end{array}$ & 22 & 20 \\
Ponerinae & $\begin{array}{l}\text { Odontomachus } \\
\text { aciculatus }\end{array}$ & 7 & 9 \\
Total abundance & & 2636 & 3183 \\
Total subfamily & & 4 & 4 \\
Total species & & 7 & 8 \\
Diversity (H') & & 0.97 & 0.88 \\
Dominance (D) & & 0.47 & 0.58 \\
Similarity (IBC) & & 0.93 & 0.93 \\
\hline
\end{tabular}

Table 2. The environmental factor between the study sites

\begin{tabular}{lcc}
\hline \multicolumn{1}{c}{$\begin{array}{c}\text { Environmental } \\
\text { factors }\end{array}$} & $\begin{array}{c}\text { Natural } \\
\text { peatland }\end{array}$ & $\begin{array}{c}\text { Oil palm } \\
\text { plantation }\end{array}$ \\
\hline Light intensity $(\operatorname{Lux})$ & 1.064 & 763 \\
Aerial temperature $\left({ }^{\circ} \mathrm{C}\right)$ & 31 & 28 \\
Soil $\mathrm{pH}$ & 5,3 & 5,3 \\
Soil humidity $(\%)$ & 52,8 & 55,3 \\
Soil temperature $\left({ }^{\circ} \mathrm{C}\right)$ & 28,5 & 28,3 \\
\hline
\end{tabular}

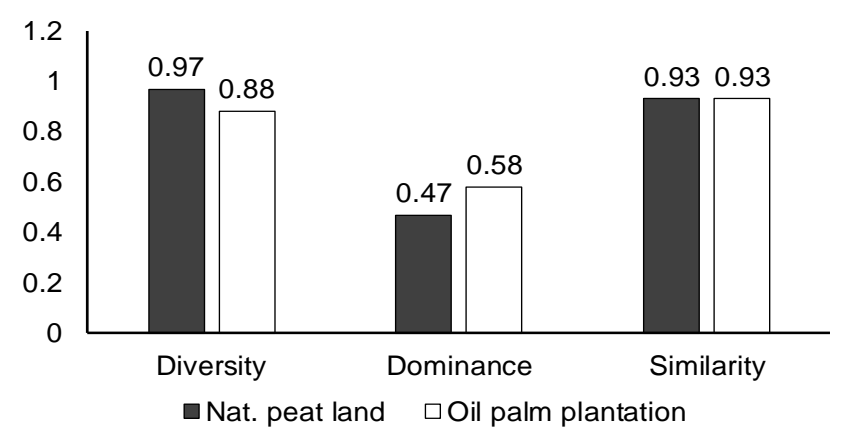

Figure 2. Diversity Index, Similarity and Dominance of Ants 


\section{Discussion}

Our study found that the two most common ant species in two locations were Dolichoderus thoracicus dan Anoplolepis gracilipes., which is because litter is still found in two locations, allowing this species to gather and make nests. In addition, the availability of vegetation also greatly affects the presence of insects because the vegetation can be used as a food source, nesting place, and shelter (Johari et al. 2019). Natural peatland generally has vegetation types in ferns, while oil palm plantation has vegetation types in ferns and oil palms. Ants from the genus Dolichoderus are commonly found in litter on the surface of the soil consisting of rotting dry leaves such as coconut, palm, banana, and cocoa leaves. Latumahina et al. (2015) stated that the genus Dolichoderus was the dominant group of ants found due to its very active and aggressive nature. In addition, ants of this genus can conduct intense competition between colonies and usually act as a forager. Thus, they are found in many types of habitats. In addition, ants of the genus Dolichoderus can dominate in disturbed environments. That is supported by Yulminarti et al. (2012) that of all the types of ants obtained, it can be seen that ants with the role of forager are the most commonly found.

The black-ant Dolichoderus thoracicus is classified as common and distributed widely in Southeast Asia (Jitjak and Sanoamuang 2019). This species is used as pest control in cocoa plantations. However, its presence in residential areas is considered disturbing, and the ant treats as a pest. Recent research reports that the ant has experienced a population increase in Taiwan and has been shown to invade human settlements frequently (Lin et al. 2021). The yellow crazy ant (Anoplolepis gracilipes) is native to Southeast Asia. It is classified as an ant that is often studied because it has an invasive nature, so it can be considered a threat to local ant species. Habitat invasion by Anoplolepis gracilipes (yellow crazy ant) harms the entire ecosystem and the interactions that occur within it. The existence of this ant species disrupts the balance in the habitat it invades and often causes the exclusion of other species that inhabit the habitat, which was reported in a study in Malaysian Borneo. The study reported that the successful establishment of A. gracilipes in anthropogenically disturbed habitats might negatively affect local ants communities through high levels of direct interspecific aggression and almost complete monopolization of resources within high-density supercolonies. The other study reported that yellow crazy ants are a significant threat to biodiversity in Hawaii due to a rapidly expanding range and the potential to disrupt ecosystem interactions at multiple trophic levels wedge-tailed shearwater (Ardenna pacifica) (Plentovich et al. 2018). This species is also reported to be an expansive species in India (Sinu et al. 2017) and Korea (Jung et al. 2017).

Oecophylla smaradigna (weaver ants) was the species with the least number, which was only found in oil palm plantations. Only two individual of this species was found because these ants generally nest in the tree canopy. Weaver ants use large trees to make nests by knitting leaves on trees. In addition, catching using a baited pitfall trap method can lure this type of ant into the trap.
Latumahina et al. (2015) also reported the same result that the ant Oecophylla smaradigna was obtained using the baiting method. Ants (Formicidae) are a large group of organisms that are colonies and forage for food outside their nest (Gesriantuti et al. 2016).

The value of the diversity index of ant species in the two locations is different, although in the same category. The diversity index value at natural peatland was slightly higher than that in the oil palm plantation. The diversity index at both locations was low because there was a dominant species, Dolichoderus thoracicus, in both study sites. The number of individuals and the number of species strongly influence the diversity index. If the number of individuals is high, the diversity index value will be small, and if the number of species is high, then the diversity index is high (Srinivasan 2009).

This study found a total of 5,819 individuals belonging to 8 ant species from all study sites. Compared with the other studies, the number of ant species in this study is relatively lower. However, our conclusion that oil palm plantations reduce diversity was consistent with the other studies. The results of research on peatlands with palm stands from a young age to old reported that 15 ant species were found (Darmi et al. 2015). Rizali et al. (2020) found 7 to 22 ant species in many oil palm plantation lands adjacent to natural habitats. Yulminarti et al. (2012) found 53 species from 316 individuals in a peat swamp forest, while the one-year-old palm oil plantation found 24 species from 237 individuals. A study in Sabah (Borneo), Malaysia, found 23 ant species baited in the plantations, nine of which differed from those inside the forest.

All numerically dominant ants were non-forest species. The most common species was Anoplolepis gracilipes, an invasive species present at $70 \%$ of all bait sites and known to cause 'ecological meltdowns' in other situations (Bruhl and Eltz 2010). Moreover, compared to the study results of Hardianti et al. (2019), the result would be more similar. That study in secondary peatlands in Kubu Raya District found 7 species from 228 individuals. The high diversity of ant species in several oil palm habitats is due to their adaptability. Ants are less sensitive to changes in land use, with a much higher degree of similarity in species assemblages across habitats than other groups, such as butterflies (Lucey and Hill 2012).

The low diversity index can be influenced by food availability and physical environmental factors (Johari et al. 2019). The research location at natural peatland generally consisted of various types of fern vegetation, which were more heterogeneous, which supported the presence of ants when compared to oil palm plantation, which was more homogeneous with only oil palm plants. In addition, environmental pressures occur in oil palm plantations in the form of land clearing, fertilization, and other human activities such as nurseries and the use of heavy equipment that can affect ant activity. These agricultural practices may affect the presence of ants.

Ant diversity is strongly influenced by food availability, vegetation, and changes in ant activity (Kovar et al. 2013; Kumar, 2017). However, several physical environmental factors obtained in the two locations in this study have a 
value difference that is not too significant. For example, the soil $\mathrm{pH}$ at both research study sites was 5.3 , the soil temperature at the natural peatland was $28.5^{\circ} \mathrm{C}$, and the oil palm plantation was $28.3^{\circ} \mathrm{C}$. According to Latumahina et al. (2015), the ideal soil $\mathrm{pH}$ range for ant life is 4.5-6.8, while Meilina et al. (2017) stated the optimum and tolerant soil temperature range is $25-32^{\circ} \mathrm{C}$. Based on this statement, the soil $\mathrm{pH}$ and temperature at natural peatland and oil palm plantations were still in optimal conditions for the survival of these ants.

Air temperature also affects the presence of ants, which affects the development of ants. Based on the results of measurements of air temperature between the two research locations are quite different. The air temperature at natural peatland has an average of $31^{\circ} \mathrm{C}$, while the air temperature at oil palm plantations has an average of $28^{\circ} \mathrm{C}$. That is because the vegetation in natural peatland does not provide canopy cover, so there is no barrier to sunlight. That causes the air temperature at natural peatland to be higher than at oil palm plantation, which has a canopy cover of palm trees. Although, generally, soil ants have an optimum temperature for growth and development, according to Meilina et al. (2017), the optimal and tolerant temperature range is $25-32^{\circ} \mathrm{C}$. Based on this statement, the air temperature in the two research locations is still optimum for the ants' survival.

Ant diversity is also affected by soil moisture. Soil moisture shows a negative correlation with ant diversity. Increased soil moisture causes various types of fauna cannot to adapt to high water content because it will be more difficult to get oxygen in the soil. If there are fauna that can adapt to soils with high water content, then this fauna dominates the area, so the diversity will decrease. The dominance index values in the two locations have different values. The natural peatland at 0.47 , while the oil palm plantation at 0.58 is in the moderate category. If the dominance index of the study site is moderate, then several species dominate the samples.

The similarity index value between the two research locations is $93 \%$. The value of this similarity index is considered high, which occurred because many identical species were found at both natural peatland and oil palm plantations. The similarity index criterion is high if the value is more than 50\%. Ecologically, the observation locations with a high similarity index value indicate that the composition of the ant species that comprise the community is relatively similar. From the results of this study, it can be emphasized that the conversion of peatland into oil palm land quantitatively affects the diversity of ants. On peatland planted with oil palm, it was found that the number of species and the number of individual ants was higher than that on peatland not planted with oil palm, with a low category diversity index.

In conclusion, in peatlands without oil palm, 7 ant species were recorded, while in oil palm peatlands, 8 species were found. Dolichoderus thoracicus and Anoplolepis gracilipes were the dominant species in the sample. The diversity of ant species in peatlands without oil palm (0.97) and peatlands planted with oil palm (0.88) was categorized as low. The dominance index on peatland without oil palm (is 0.47 ), while peatland planted with oil palm (0.58) is considered moderate. The similarity index was considered high. Therefore, efforts to preserve the habitat of ants by maintaining their microhabitat and resource, as well as conserving the important species such as natural enemies of pests, need to be taken into account in peatland management.

\section{REFERENCES}

Bruhl CA, Eltz T. 2010. Fuelling the biodiversity crisis: Species loss of ground-dwelling forest ants in oil palm plantations in Sabah, Malaysia (Borneo). Biodivers Conserv 19: 519-529. DOI: 10.1007/s10531-0099596-4.

Calabuig A, Garcia-Marí F, Pekas A. 2015. Ants in citrus: Impact on the abundance, species richness, diversity and community structure of predators and parasitoids Agric Ecosys Environ 213: 178-185. DOI: 10.1016/j.agee.2015.08.001.

Carvalheiro LG, Seymour CL, Nicolson SW, Veldtman R. 2012. Creating patches of native flowers facilitates crop pollination in large agricultural fields: Mango as a case study. J Appl Ecol 49: 13731383. DOI: 10.1111/j.1365-2664.2012.02217.x.

Chen YQ, Li Q, Chen YL, Zhou X. 2011. Ant diversity and bio-indicators in land management of lac insect agroecosystem in Southwestern China. Biodivers Conserv 20: 3017-3038. DOI: 10.1007/s10531-0110097-x.

Darmi, Budianta D, Sabaruddin M, Ridho R.2015. Communities of ants (Hymenoptera: Formicidae) in peatland planted with oil palm stands of different age strata. Adv Environ Biol 9 (3): 473-480.

de Queiroz ACM, Rabello AM, Braga DL, Santiago GS, Luana F, Zurlo LF, Philpott SM, Ribas CR. 2020. Cerrado vegetation types determine how land-use impacts ant biodiversity. Biodivers Conserv 29: 20172034. DOI: 10.1007/s10531-017-1379-8.

Diame L, Blatrix R, Grechi I, Rey J, Sane CAB, Vayssieres J, de Bon H, Diarra K. 2015. Relations between the design and management of Senegalese orchards and ant diversity and community composition. Agric Eco Environ 212: 94-105. DOI:10.1016/j.agee.2015.07.004.

Fitzherbert EB, Struebig MJ, Morel A, Danielsen F, Brühl CA, Donald PF, Phalan B. 2008. How will oil palm expansion affect biodiversity? Trends Ecol Evol 23 (10): 538-545. DOI: 10.1016/j.tree.2008.06.012.

Gesriantuti N, Trantiati R, Badrun Y. 2016. Keanekaragaman serangga permukaan tanah pada lahan gambut bekas kebakaran dan hutan lindung Di Desa Kasang Padang, Kecamatan Bonaidarusalam, Kabupaten Rokan Hulu, Provinsi Riau. Jurnal Photon 7 (1):147-155. DOI: 10.37859/jp.v7i01.569. [Indonesian]

Hardianti D, Prayogo H, Indrayani Y. 2019. Diversitas semut (Hymenoptera : Formicidae) pada lahan gambut di Desa Kuala Dua Kabupaten Kubu Raya. Jurnal Hutan Lestari 7 (2): 868-873. DOI: 10.26418/jhl.v7i2.34553. [Indonesian]

Hosoishi S, Ngoc LA, Yamane S, Ogata K. 2013. Ant diversity in rubber plantations (Hevea brasiliensis) of Cambodia (Hymenoptera: Formicidae). Asian Myrme 5: 69-99.

Jitjak W, Sanoamuang N. 2019. A novel fungus, Mycodomus formicartus associated with black ant, Dolichoderus thoracicus (Smith) on bamboo. Asia-Pac J Sci Technol 24 (3): 1-15.

Johari A, Natalia D, Handayani F, Haryadi B. 2019. The relationship between the abundance of thrips species (Thysanoptera) and the existence of host plants in vegetable plantations in South Jambi, Indonesia. J Entomol Res 43 (2): 173-178. DOI: 10.5958/09744576.2019.00034.3

Jung JM, Jung S, Ahmed MR, Cho BK, Lee WH. 2017. Invasion risk of the Yellow crazy ant (Anoplolepis gracilipes) under the representative concentration pathways 8.5 climate change scenario in South Korea. J Asia-Pac Biodivers 10: 548-554. DOI: 10.1016/j.japb.2017.08.004.

Kovar P, Vojtíšek P, Zentsova I. 2013. Ants as ecosystem engineers in natural restoration of human made habitats. J Lands Ecol 6 (1): 18-31. DOI: $10.2478 / \mathrm{v} 10285-012-0061-9$.

Kumar R. 2017. Ants as engineers of biodiversity and ecosystem. Int J Adv Sci Res 6 (1): 744-746.

Latumahina F, Musyafa, Sumardi, Putra NS. 2015. Respon semut terhadap kerusakan antropogenik dalam hutan lindung sirimau 
Ambon. Jurnal Manusia dan Lingkungan 22 (3): 176. DOI: 10.22146/jml.18739. [Indonesian]

Lin WJ, Chiu MC, Lin CC. 2021. Efficacy of entomopathogenic fungus Aspergillus nomius against Dolichoderus thoracicus. BioControl 66 (4): 463-473. DOI: 10.1007/s10526-021-10086-7.

Lucey JM, Hill JK 2012. Spillover of insects from rain forest into adjacent oil palm plantations. Biotropica 44: 368-377. DOI: $10.1111 /$ j.17447429.2011.00824.x.

Lucey JM,Tawatao N, Senior MJM, Chey VK, Benedick S, Hamer KC et al. 2014. Tropical forest fragments contribute to species richness in adjacent oil palm plantations. Biol Conserv 169: 268-276. DOI: 10.1016/j.biocon.2013.11.014.

Martínez-Ferrer MT, Campos-Rivela JM. 2017. Diversity, spatial distribution, and sampling for ant management decision-making in integrated pest management programs in citrus groves. Entomol Exp Appl 162: 251-260. DOI: 10.1111/eea.12535.

Meilina D, Setyawati TR, Yanti AH. 2017. Ragam jenis semut (Hymenoptera: Formicidae) di lahan gambut alami dan perkebunan sawit di kecamatan Sungai Ambawang Kabupaten Kubu Raya. Jurnal Protobiont 6 (3): 68-74.

Odum EP, Barrett G. 2004. Fundamentals of Ecology. Cengage Learning

Plentovich S, Russell T, Fejeran CC. 2018. Yellow crazy ants (Anoplolepis gracilipes) reduce numbers and impede development of a burrow-nesting seabird. Biol Invasions 20: 77-86. DOI: 10.1007/s10530-017-1516-z.

Rizali A, Karindah S, Windari A, Rahardjo B, Nurindah, Shari B. 2020. Ant and termite diversity in Indonesian oil palm plantation: Investigating the effect of natural habitat existence. Biodiversitas 21 (4): 1326-1331. DOI: 10.13057/biodiv/d210408.

Schmidt FA, Ribas CR, Schoereder JH. 2013. How predictable is the response of ant assemblages to natural forest recovery? Implications for their use as bioindicators. Ecol Indic 24: 158-166. DOI: 10.1016/j.ecolind.2012.05.031.

Sinu PA, Sibisha VC, Reshmi MVn et al. 2017. Invasive ant (Anoplolepis gracilipes) disrupts pollination in pumpkin. Biol Invasions 19: 25992607. DOI: 10.1007/s10530-017-1470-9.

Sodhi NS, Posa MRC, Lee TM et al .2010. The state and conservation of Southeast Asian biodiversity. Biodivers Conserv 19: 317-328. DOI: 10.1007/s10531-009-9607-5.

Srinivasan R. 2009. Insect and Mite Pests on Eggplant. Avrdc - The World Vegetable Center.

Suguituru SS, Silva RR, Souza DRD, Munhae CDB, Morini MSDC. 2011. Ant community richness and composition across a gradient from Eucalyptus plantations to secondary Atlantic Forest. Biota Neotrop 11 (1): 369-376. DOI: 10.1590/S1676-06032011000100034.

Tsujino R, Yumoto T, Kitamura S, Djamaluddin I, Darnaedi D. 2016. History of forest loss and degradation in Indonesia. Land Use Policy 57: 335-347. DOI: 10.1016/j.landusepol.2016.05.034.

Urrutia-Escobar MX, Armbrecht I. 2013. Effect of two agroecological management strategies on ant (Hymenoptera: Formicidae) diversity on coffee plantations in Southwestern Colombia. Environ Entomol 42 (2): 194-203. DOI: 10.1603/EN11084.

Wang WY, Foster A. 2015. The effects of forest conversion to oil palm on ground-foraging ant communities depend on beta diversity and sampling grain. Ecol Evol 5 (15): 3159-3170. DOI: $10.1002 /$ ece 3.1592 .

Yashimoto Y. 2003. Manual for Bornean Ant (Formicidae) Identification. University Malaysia Sabah, Kinabalu.

Yulminarti S, Salmah S, Subahar TSS. 2012. Number of ant species and individuals in natural peat-land and peat-land of oil palm plantation in Pagar River, Riau. Biospecies 5 (2): 21-27. 